\title{
SUMMARY
}

\section{OVERVIEW OF THE RISK MANAGEMENT FRAMEWORK OF INLAND TRANSPORT OF DANGEROUS GOOD}

The paper defines dangerous goods, the concept of risk and presents a framework for risk assessment of Inland transport of dangerous goods. In order to improve the risk assessment of this area, a framework has been developed on the basis of which inequalities will be eliminated in practice and in the legal sense. The paper presents an overview of the steps of the case study description and risk assessment of the transport of dangerous goods, on the basis of which the necessary prevention measures are applied in order to reduce the risk to a tolerable level. Improving the functioning of the risk assessment framework is done by harmonizing the best methodology of the expert's work and based on the feedback of the results during its use.

Key words: dangerous goods, risk assessment, risk assessment framework

\section{Извињење}

Извињавамо се ауторима рада „Супституција вида транспорта опасне робе и њени ефекти“ који је публикован у часопису „Техника“ број 1/2021, сепарат „Менаџмент“, јер је приликом техничке припреме часописа за публиковање, грешком изостављено име господина Синише Сремца, једног од аутора рада. У часопису је наведено да су аутори рада Драган Смиљанић, Гордан Стојић и Милош Копић, док је требало да стоји да су аутори предметног рада Драган Смиљанић, Синиша Сремац, Гордан Стојић и Милош Копић. 